\title{
URANIUM CONTENT OF THE FISKENÆSSET ANORTHOSITE COMPLEX AT MAJORQAP QÂVA
}

\author{
John S. Myers
}

The uranium content of 25 samples from the Majorqap qâva outcrop of the Fiskenæsset anorthosite complex were determined to obtain an outline of the uranium distribution both in the different major rock types and at different stratigraphic levels within this layered igneous complex. Analyses were made at the Danish Atomic Energy Commission Research Establishment at Ris $\varnothing$ by delayed neutron counting following neutron activation, under the direction of Leif L $\varnothing$ vborg early in 1973.

The Majorqap qâva outcrop is divided into four major units which are in upward succession: lower leucogabbro $(50 \mathrm{~m})$, gabbro $(40 \mathrm{~m})$, upper leucogabbro $(60 \mathrm{~m})$, and anorthosite $(200 \mathrm{~m})$. The main rock types are metamorphosed and partly metamorphosed anorthosite, leucogabbro, gabbro, and ultramafic rock, which chiefly consist of plagioclase (An 80-98) and green hornblende, with minor amounts of biotite, pyroxene, olivine, spinel, magnetite and chromite.

In general the variation of uranium content both within a single stratigraphic unit and between samples of the same rock types is almost as great as the variation within the whole complex. In two places however, where samples were collected at measured stratigraphic intervals, the uranium content shows a systematic upward decrease (fig. 34). The first suite of samples (fig. 34, line A) spans the whole of the gabbro, upper leucogabbro and anorthosite units, whereas the second suite of samples (fig. 34, line B) spans only $150 \mathrm{~cm}$ across a composition graded ultramafic and gabbro layer within the lower leucogabbro unit. The latter shows the clearest decrease of uranium content with height in the succession (fig. 33).

All the samples analysed are either completely or partly recrystallised after igneous mineral assemblages and much of the irregular variation of uranium content may be due to this metamorphism. In order to understand the original distribution of uranium in this

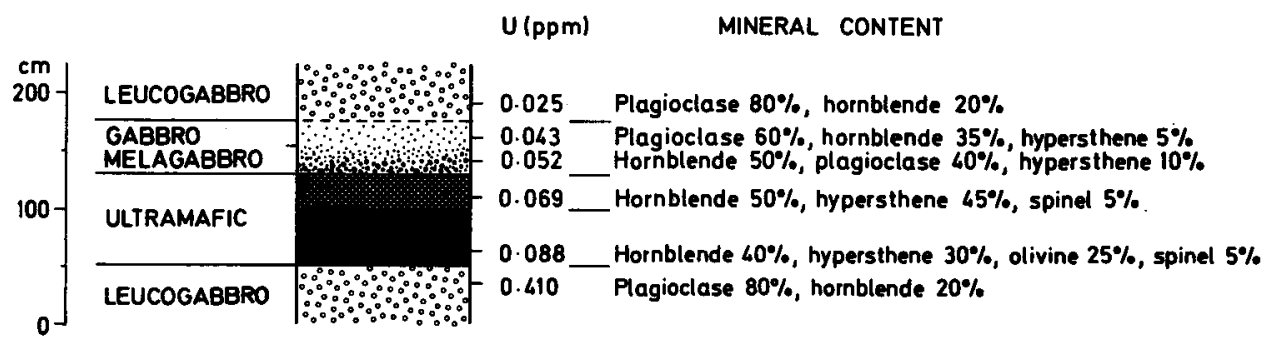

Fig. 33. The uranium content of a composition-graded ultramafic layer in the lower leucogabbro unit. 
layered igneous complex, analyses of individual minerals in places where primary igneous assemblages are preserved are required, but these preliminary analyses suggest that uranium was generally concentrated in the earliest formed minerals.

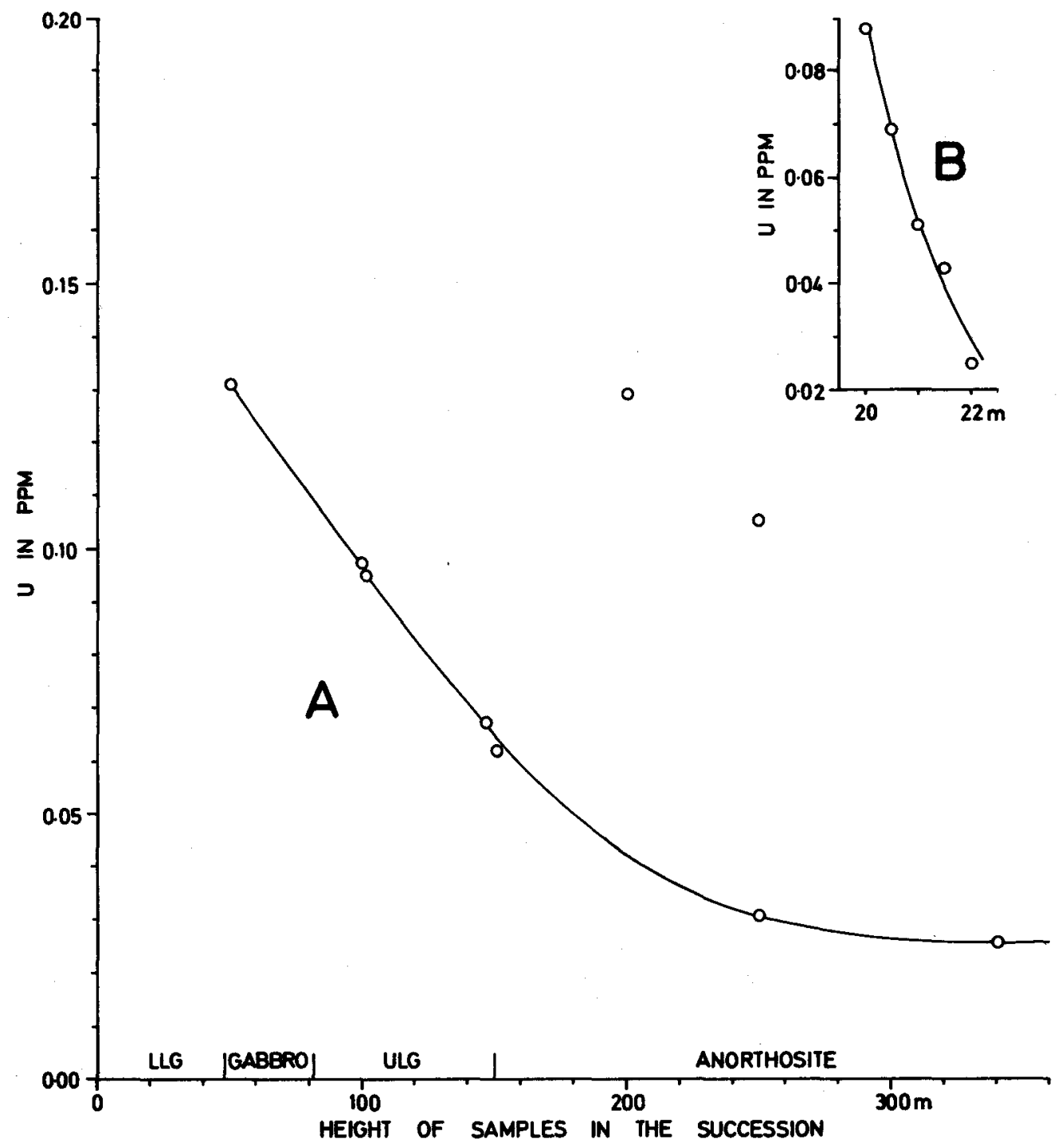

Fig. 34. The relationship between uranium and stratigraphic position: $A$ in the gabbro, upper leucogabbro and anorthosite units. B across a composition-graded ultramafic layer in the lower leucogabbro unit (shown in fig. 33). 